\title{
Origins of...
}

\section{Telomerase in the early detection of cancer}

\author{
J W Shay, A F Gazdar
}

Telomerase activity is present in almost all carcinomas. There are increasing numbers of studies indicating the utility of telomerase assays in the early detection of cancer, and in the present review, we summarise the state of the field.

\section{Telomere-telomerase theory of ageing and cancer}

The telomere-telomerase hypothesis of ageing has become a new model for carcinogenesis studies. ${ }^{1-9}$ The hypothesis is based on the findings that most normal human somatic cells do not have detectable telomerase activity, whereas most human tumours have shortened telomeres and express telomerase activity. ${ }^{6}$ Telomeres are thought to provide genomic stability to the ends of all linear chromosomes and permit the complete replication of the chromosomes. ${ }^{10-12}$ Telomere length is maintained by a balance between processes that lengthen telomeres (for example, telomerase ${ }^{13}$ ) and processes that shorten telomeres (for example, end-replication problem ${ }^{14}{ }^{15}$ ). Telomerase is a ribonucleoprotein enzyme which stabilises telomere length by adding hexameric (TTAGGG) repeats ${ }^{16}$ to the telomeric ends of the chromosomes, thus compensating for the continued erosion of telomeres that occurs in its absence. ${ }^{14}{ }^{15}$ The enzyme is expressed in embryonic cells ${ }^{17}$ and in adult male germline cells, ${ }^{617}$ but is undetectable in normal somatic cells except for proliferative cells of renewable tissues (for example, haemopoietic stem cells and activated lymphocytes, ${ }^{18-21}$ basal cells of the epidermis, ${ }^{22}{ }^{23}$ and intestinal crypt cells ${ }^{24}$ ). In normal somatic cells, progressive telomere shortening is observed, and it has been proposed that this may lead to greatly shortened telomeres and to a limited replicative capacity. ${ }^{25} 26$ Although most of the evidence that telomere shortening may be a molecular measure (clock) of the proliferative potential remaining in cells is correlative, ${ }^{25-27}$ recently more direct evidence for a causal role of telomere shortening in ageing has been obtained. ${ }^{28}$

Although all of the steps leading to cancer are not yet known, progression to a cancerous state requires the accumulation of a series of genetic alterations. An emerging hypothesis suggests that the up regulation or re-expression of telomerase is a critical event responsible for continuous tumour cell growth. ${ }^{19}$ In contrast to normal cells, tumour cells show no net loss of average telomere length with cell division, suggesting that telomere stability may be required for cells to escape replicative senescence and proliferate indefinitely. Immortalisation may occur through mutation of a gene in the telomerase repression pathway, permitting the expression of telomerase and the maintenance of telomere stability in cancer cells. Thus, it is becoming generally accepted that the up regulation ${ }^{7}$ or reactivation ${ }^{8}$ of telomerase activity may be a rate limiting, if not the critical, step required for the continuing proliferation of advanced cancers. This review focuses on the question of the timing of reactivation of telomerase in cancer progression and whether telomerase may be a new and independent early indicator of cancer.

\section{Telomerase activity assay}

A highly sensitive, PCR-based assay for measuring telomerase activity has been developed that includes an improved detergent lysis method to allow more uniform extraction of telomerase from a small number of cells. ${ }^{6}$ In the TRAP (telomeric repeat amplification protocol) assay, telomerase first synthesises extension products which then serve as templates for PCR amplification. The simplicity and increased sensitivity of this assay has resulted in a dramatic increase in investigations of telomerase expression..$^{29-52}$ Although the amplification protocol for measuring telomerase activity is straightforward and relatively easy to use, there are concerns about variability between laboratories. More recently, improvements in the assay include an internal standard to permit semiquantitation of levels of telomerase activity and to allow for the detection of inhibitors of amplification that may be present in some tissue extracts. ${ }^{45}$ In addition, non-radioactive methods for detecting telomerase have been reported, ${ }^{20}$ and most pathological specimens can be used including exfoliated cells, fine needle aspirates and single $5 \mu \mathrm{m}$ frozen sections (box 1). With the introduction of a research kit (TRAPeze) for detecting telomerase activity (Oncor, Gaithersburg, Maryland, USA), reproducibility between laboratories is likely to improve. ${ }^{46}$ However, as telomerase activity is also present in activated lymphocytes, continual clinicopathological correlations will be required in the interpretation of this activity in tissue extracts.

Texas 75235-9039, DSA e-mail:

Accepted for publication 9 December 1996 
Requirements for telomerase to be a surrogate marker for early detection of cancer

There is increasing interest in identifying molecular markers which could ultimately replace the older anatomically or cytologically oriented methods for the early detection of cancer. With the knowledge that telomerase activation occurs so frequently in cancer, there is the possibility that telomerase detection could be put to use in screening. Criteria that should be considered when evaluating whether a new marker, such as telomerase, will be useful in early detection or risk assessment include some of the following: is the biomarker differentially expressed in normal and high-risk tissue; at what stage of progression does the biomarker appear; what is the association with clinical outcome; what are the acceptable specificities, sensitivities and accuracies of the assay; and can those cancers that are going to progress be distinguished from those cancers that are not? The usefulness of validating whether telomerase is such a marker is that it may affect the duration of clinical trials, require a smaller sample size, and reduce costs.

Box 1

Measurement of telomerase activity in clinical specimens

- Frozen sections and fine needle aspirates: many cancers

- Normal secretions (urine, cerebrospinal fluid): bladder, prostate, cancers of the central nervous system, brain metastases

- Pathological fluids (effusions, ascites): lung, liver, pancreas, breast, colon, stomach, ovary

- Aspirates (pancreatic, biliary, mammary): pancreas, liver, gall bladder, bile duct, breast

- Washes and brushes (oral, colon, biliary, lung): head and neck, colon, bile duct, cervix, lung

Overview of studies of telomerase activity in the early detection of cancer

Telomerase activity can be detected in most primary human tumour specimens and tumour-derived cell lines. Telomerase activity is detected in the most common cancers, such as those of the prostate, ${ }^{29}$ breast, ${ }^{37}{ }^{41}$ colon, ${ }^{24} 3142{ }^{43}$ lung, ${ }^{35}$ and liver ${ }^{30}{ }^{47}$ in $85-95 \%$ of patients examined and in many instances at an in situ stage. In breast and lung cancer, telomerase activity appears very early (even in preneoplasia of smokers and former smokers), whereas in others, such as pancreatic ${ }^{48}$ and colon cancer, it appears in $90-95 \%$ of early stage carcinomas but not in preneoplasia (box 2). There is evidence in neuroblastoma, ${ }^{34}$ acute myeloid leukaemia, ${ }^{32}{ }^{38}$ breast, ${ }^{3741}$ and gastrointestinal cancers ${ }^{3136}$ that the presence of high levels of telomerase correlates with poor prognosis.

Telomerase activity can be detected in almost any type of clinical specimen including exfoliated cells and fine needle aspirates (box 1 ). The measurement of telomerase in cells sedimented from voided urine for bladder cancer is potentially promising if reproducible methods to maintain the activity are devised. ${ }^{49} 50$ The use of minimally invasive procedures such as fine needle aspiration ${ }^{37} 41$ of breast masses have great promise for distin- guishing carcinoma from benign disease; future studies using cells obtained from nipple aspirates should be considered. The use of cytological samples obtained by flexible fibre optic bronchoscopy and by thoracocentesis in identifying lung carcinoma may also be useful in some instances ( $\mathrm{K}$ Hiyama, personal communication). Oral rinses (D Sidransky, personal communication) may predict premalignant leucoplakia lesions capable of progressing to carcinoma, ${ }^{44}$ and colonic washes ${ }^{51}$ may be useful in detecting early stage colorectal carcinoma, but more studies are required. It is also possible that the presence of telomerase activity may be a marker of minimal residual disease in patients undergoing chemotherapy, and that the detection of telomerase activity may be a useful surrogate end point marker for following efficacy of chemoprevention trials. In a recent study, ${ }^{52}$ less than $20 \%$ of ordinary meningiomas were shown to have telomerase activity, whereas those meningiomas that had detectable telomerase activity had a very high probability of tumour recurrence. Additional prospective and independently confirmed studies are clearly warranted. Similarly, additional studies using brushings to analyse telomerase activity in pancreatic secretions, ${ }^{48}$ and fine needle or core biopsy specimens for distinguishing thyroid adenomas from carcinomas (S Sukumar, personal communication), or benign prostatic hyperplasia from prostate cancer $^{29}$ may be useful.

\begin{tabular}{|l|}
\hline Box 2 \\
\hline Telomerase activity in cancer: \\
activation stage \\
- Early in pathogenesis: breast, head and neck, \\
lung; skin cancer (sun-damaged skin); hepatocel- \\
lular carcinoma (hepatitis, cirrhosis) \\
- Late in pathogenesis: colon, pancreas and thyroid \\
cancers \\
- Insufficient or conflicting data: ordinary meningi- \\
omas, renal, ovary, prostate, and stomach cancers
\end{tabular}

In breast and lung cancer, telomerase activity is present at a very early stage. As an example, we recently examined multiple specimens of lung and bronchial epithelium at different distances from the invasive tumour from 10 patients undergoing surgery. Frozen sections of samples of carcinoma in situ obtained by fluorescence bronchoscopy were also examined. Although most of these patients examined were smokers or former smokers, one patient, a non-smoker, without cancer did not have any detectable telomerase activity in any sample examined. In the specimens obtained from smokers and former smokers with and without lung cancer, $15 \%$ of histologically normal epithelium expressed low but detectable levels of telomerase activity. A progressively higher percentage of samples with hyperplasia, metaplasia and dysplasia had detectable telomerase activity and all five samples of carcinoma in situ had activity. The relative amounts of telomerase activity in preneoplastic specimens and in the carcinoma in situ, even after adjustment for the number of epithelial cells in the specimen, were approximately 10-fold lower than in the corresponding tumour. In addition, the 
presence of telomerase activity in preneoplasia of the lung correlated with microsatellite alterations and loss of heterozygosity at chromosomes $3 p$ and $9 p$. Such observations are consistent with the "field-theory" of lung cancer pathogenesis. So although there are low levels of telomerase activity early during pathogenesis of lung cancer of smokers and former smokers, its activity is up regulated in invasive cancer.

\section{Future directions}

There are many aspects of the complex biology and basic regulation of telomerase that we do not yet understand. Additional studies on the regulation of telomere length and telomerase activity are clearly warranted. This would include better methods for measuring telomere lengths, better telomerase extraction methods, and identification of genes regulating the repression pathway of telomerase. In addition, alternate pathways to immortality clearly exist $^{6354}$ in cell culture models of immortalisation. For example, in one series of experiments, Murnane $e t a b^{3}$ examined telomere shortening in a line of SV40 immortalised human fibro-blasts that lacked telomerase activity. In cells transfected with a marker plasmid, the rate of loss of telomeric repeats was similar to that found in normal cultured human fibroblasts; however, when the telomere had become critically shortened, many kilobases of telomere repeats were added rapidly. The rapid increase in telomere length was attributed to non-reciprocal recombination by analogy to the results in yeast. Although very long and heterogeneous telomere lengths are found in the absence of detectable telomerase activity in some virally transformed cells in culture, the existence or role of such alternate pathways in primary human cancer is undefined as yet.

Although there is hope that studying aspects of telomerase in animal models of carcinogenesis may yield insights into basic mechanisms of telomere and telomerase regulation, it would not be surprising if many aspects of the regulation of telomeres and telomerase are species specific. In addition, most studies have reported that measurements of telomere length are unlikely to be of use in early detection of cancer. ${ }^{6}$ However, there is some evidence that measurements of telomere length may be a useful indicator when telomerase activity is not raised. ${ }^{40}$ Importantly, we have learned that the detection of telomerase activity only indicates the potential for cellular immortality and is not always synonymous with cancer. ${ }^{9}$ In some cases of metastatic neuroblastoma, tumours are observed that eventually undergo remission, ${ }^{34}$ so "mortal" tumours are not incompatible with the telomere-telomerase theory of ageing and cancer. Cell immortality does not confer unregulated rates of cell proliferation, invasiveness, or metastasis, but only gives the cells the proliferative capacity to accumulate the necessary mutations to become malignant. Because cancer is diverse, some tumours may need only a few mutations in order to become malignant and may not exhaust the normal limits of proliferation before they cause disease. These types of tumour would be expected to be both mortal and negative for telomerase activity. Thus, in these special cases of neuroblastoma, the very lack of or low expression of telomerase activity was insufficient to maintain telomere length so that the cells eventually developed critically shortened telomeres and underwent growth arrest. ${ }^{34}$ So far this is the best evidence that telomerase activity is likely to be required for the continued proliferation of tumour cells.

Interpretation of telomerase activity in tissue extracts is also complicated by quiescence of telomerase-competent cells, telomerase expression by inflammatory cells, and telomerase assay inhibitors. ${ }^{9}$ Thus, repression of telomerase activity in quiescence suggests that different levels of telomerase in tumour biopsy specimens may reflect the fraction of proliferating cells. $^{95}$ This indicates that there is a need for the development of an assay to measure telomerase activity in situ, and to determine whether in situ analysis of telomerase $\mathrm{RNA}^{56}$ is a useful adjunct to telomerase activity assays conducted on tissue extracts. In a preliminary series of experiments ( 110$)$, we showed that in situ hybridisation of human telomerase RNA to archival paraffin wax embedded malignant lymph nodes could easily distinguish cancer from normal cells. In addition, telomerase inhibitors are being actively considered as potential anti-tumour agents, with the hope that the lack of telomerase expression in normal somatic cells would result in a highly specific treatment with fewer side effects than conventional chemotherapy. ${ }^{57}$ As the most primitive stem cells of renewable tissues are generally quiescent, ${ }^{9}$ future combined chemotherapeutic strategies may be designed to include conventional treatments to reduce tumour mass, a recovery period to permit primitive stem cells (recruited to replace damaged regenerating tissues) to return to quiescence, followed by anti-telomerase treatments to limit the proliferative capacity of surviving tumour cells. ${ }^{9}$ Finally, studies comparing other early cancer detection biomarkers with telomerase activity should be encouraged.

\section{Summary}

Although there is justifiable optimism regarding telomerase activity and early detection of cancer, it is important to point out that there is much that remains to be understood and additional validation studies will be required before knowledge of telomerase activity will be useful in decisions regarding patient management. A key question is whether we will be able to distinguish those cancers that are going to progress from those cancers that are not by detecting telomerase activity. Molecular staging using markers such as telomerase activity in combination with other molecular markers may be particularly useful in this regard. Basic scientists and clinicians must work together if this strategy is to mature. Telomerase inhibitors in the treatment of cancer are awaited with great anticipation.

This work was supported by research grants from the National Institutes of Health (AG07992); the Geron Corporation, Menlo Park, CA; Texas Advanced Technology Program (003660-041); 
USAMR grants (DAMD17-94-J-4077); and the Susan Komen Breast Cancer Foundation. We thank Dr S Srivastava of the Early Detection Branch of the NCI and the scientists who participated and were willing to share preliminary and, in many cases, unpublished data at the NCI sponsored Workshop (June, 1996) Telomerase activity and the early detection of cancer.

1 Bacchetti, S, Counter, CM. Telomeres and telomerase in human cancer. Int $\mathcal{F}$ Oncol 1995;7:423-432.

2 Shay JW, Wright WE. Telomerase activity in human cancer. Curr Opin Oncol 1996;8:66-71.

3 de Lange T. Activation of telomerase in a human tumor. Proc Natl Acad Sci USA 1994;91:2882-5.

4 Counter CM, Avilion AA, LeFeuvre CE, Stewart NG, Greider CW, Harley CB, et al. Telomere shortening associated with chromosome instability is arrested in immortal cell which express telomerase activity. EMBO $\mathcal{F} 1992 ; 11: 1921$ 9.

5 Counter CM, Hirte HW, Bacchetti S, Harley CB. Telomerase activity in human ovarian carcinoma. Proc Natl Acad Sci USA 1994;91:2900-4.

6 Kim NW, Piatyszek MA, Prowse KR, Harley CB, West MD, Ho PLC, et al. Specific association of human telomerase activity with immortal cells and cancer. Science 1994;266: 2011-15.

7 Greaves $M$. Telomerase activation, stem cells and cancer. Trends Genet 1996;12:127-8.

8 Shay JW, Wright WE. The reactivation of telomerase activity in cancer progression. Trends Genet 1996;12:129-31.

9 Holt SE, Shay JW, Wright WE. Refining the telomeretelomerase hypothesis of aging and cancer. Nature Biotechnology 1996;14:836-40.

10 Blackburn EH. Structure and function of telomeres. Nature 1991;350:569-73.

11 Blackburn EH. Telomeres: no end in sight. Cell 1994;77: $621-3$.

12 Greider C. Mammalian telomere dynamics: healing, fragmentation shortening and stabilization. Curr Opin Genet Dev 1994;4:203-11.

13 Morin GB. The human telomerase terminal transferase enzyme is a ribonucleoprotein that synthesizes TTAGGG repeats. Cell 1989;59:521-9.

14 Olovnikov AM. Priniples of marginotomy in template synthesis of polynucleotides. Doklady Akademii Nauk SSSR 1971;201:1496-9.

15 Watson JD. Origin of concatameric T7 DNA. Nature New Biology (London) 1972;239:197-201

16 Moyzis RK, Buckingham JM, Cram LS, Dani M, Deaven LL, Jones MD, et al. A highly conserved repetitive DNA sequence, (TTAGGG) ${ }_{n}$, present at the telomeres of human chromosomes. Proc Natl Acad Sci USA 1988;85:6622-6.

17 Wright WE, Piatyszek MA, Rainey W'E, Byrd W, Shay JW. Telomerase activity in human germline and embryonic tissues and cells. Dev Genet 1996;18:173-9.

18 Hiyama K, Hirai Y, Kyoizumi S, Akiyman M, Hiyama E Piatyszek MA, et al. Activation of telomerase in human lymphocytes and hematopoietic progenitor cells. F Immunol 1995;155:3711-15.

19 Broccoli D, Young JW, de Lange T. Telomerase activity in normal and malignant hematopoietic cells. Proc Natl Acad Sci USA 1995;92:9082-6.

20 Piatyszek MA, Kim NW, Weinrich SL, Hiyama K, Hiyama $\mathrm{E}$, Wright WE, et al. Detection of telomerase activity in human cells and tumors by a telomeric repeat amplification protocol (TRAP). Methods Cell Sci 1995;17:1-15.

21 Chiu CP, Dragowska W, Kim NW, Vaziri H, Yui J, Thomas $\mathrm{TE}$, et al. Differential expression of telomerase activity in hematopoietic progenitors from adult human bone marhematopoietic progenitors from

22 Taylor RS, Ramirez RD, Ogoshi M, Chaffins M, Piatyzsek MA, Shay JW. Telomerase activity in malignant and nonmalign

23 Harle-Bachor C, Boukamp P. Telomerase activity in the regenerative basal layer of the epidermis in human skin and in immortal and carcinoma-derived skin keratinocytes. Proc Natl Acad Sci USA 1996;93:6476-81.

24 Hiyama E, Hiyama K, Tatsumoto N, Shay JW, Yokoyama T. Telomerase activity in human intestine. Int f Oncol 1996;9: 453-8.

25 Harley CB. Telomere loss: mitotic clock or genetic time bomb? Mutat Res 1991;256:271-82.

26 Harley CB. Telomeres and aging: fact, fancy, and the future Fournal of the National Institutes of Health 1995;7:64-8.

27 Allsopp RC, Vaziri H, Patterson C, Goldstein S, Youngla $\mathrm{EV}$, Futcher $\mathrm{AB}$, et al. Telomere length predicts replicative capacity of human fibroblasts. Proc Natl Acad Sci USA 1992;89: 10114-8.

28 Wright WE, Brasiskyte D, Piatyszek MA, Shay JW. Experimental elongation of telomeres in immortal huma cells extends the lifespan of immortal $x$ normal cell hybrids. EMBO ₹ 1996;15:1734-41.

29 Sommerfeld HJ, Meeker AK, Piatyszek MA, Bova GS, Shay JW, Coffey DS. Telomerase activity distinguishes benign
from malignant human prostate tissue. Cancer Res $1996 ; 56$ : 218-22.

30 Tahara H, Nakanishi T, Kitamoto M, Nakashio R, Shay JW, Tahara $\mathrm{E}$, et al. Telomerase activity in human liver tissues: correlation between chronic liver disease and hepatocellular carcinoma. Cancer Res 1995;55:2734-6.

31 Tahara H, Kuniyasu H, Yasui W, Yokozaki H, Shay JW, Ide $\mathrm{T}$, et al. Telomerase activity in gastric and colorectal carcinomas correlates well with malignant progression. Clinical Cancer Research 1995;1:1245-51.

32 Counter CM, Gupta J, Harley CB, Leber B, Bacchetti S. Telomerase activity in normal leukocytes and in hematologic malignancies. Blood 1995;85:2315-20.

33 Langford LA, Piatyszek MA, Xu R, Schold SC, Shay JW. Telomerase activity in human brain tumors. Lance 1995;346: 1267-8

34 Hiyama E, Hiyama K, Yokoyama T, Matsuura Y, Piatyszek MA, Shay JW. Correlating telomerase activity levels with human neuroblastoma outcomes. Nat Med 1995;1:249-55.

35 Hiyama K, Hiyama E, Ishioka S, Yamakido M, Inai $\mathrm{K}$, Gazdar AF, et al. Telomerase activity in small-cell and nonsmall-cell lung cancers. $\mathcal{F}$ Natl Cancer Inst 1995;87:895902 .

36 Hiyama E, Yokoyama T, Tatsumoto N, Hiyama K, Imamura $\mathrm{Y}$, Murakami Y, et al. Telomerase activity in gastric cancer. Cancer Res 1995;55:3258-62.

37 Hiyama E, Gollahon L, Kataoka T, Kutoi K, Yokoyama T, Gazdar AF, et al. Telomerase activity in human breast tumors. F Natl Cancer Inst 1996;88:116-22.

38 Zhang W, Piatyszek MA, Estey E, Kobayashi T, Andreff M Deisseroth AB, et al. Telomerase activity in acute myelogenous leukemia: Inhibition of telomerase activity by differentiation-inducing agent. Clin Cancer Res 1996;2: 799-803.

39 Mehle C, Piatyszek MA, Ljungberg B, Shay JW, Roos G. Telomerase activity in human renal cell carcinoma. Oncogene 1996;13:161-6.

40 Shay JW, Werbin $\mathrm{H}$, Wright WE. Telomeres and telomerase in human leukemias. Leukemia 1996;10:1255-61.

41 Sugino T, Yoshida K, Bolodeoku J, Tahara H, Buley I, Manek S, et al. Telomerase activity in human breast cancer and benign breast lesions: Diagnostic applications in clini$\mathrm{cal}$ specimens including fine needle aspirates. Int $\mathcal{F}$ Cance 1996;69:301-6.

42 Chadeneau C, Hay K, Hirte HW, Galligner S, Bacchetti S. Telomerase activity associated with acquisition of malignancy in human colorectal cancer. Cancer Res 1995;55: nancy in

43 Li Z-H, Salovaara R, Aaltonen LA, Shibata D. Telomerase activity is commonly detected in hereditary nonpolyposis colorectal cancer. Am F Pathol 1996;148:1075-9.

44 Mutirangura A, Supiyaphun P, Trirekapan S, Sriuranpong $\mathrm{V}$, Sakuntabhai A, Yenrudi S, et al. Telomerase activity in oral leukoplakia and head and neck squamous cell carcinoma. Cancer Res 1996;56:3530-3.

45 Wright WE, Shay JW, Piatyszek MA. Modification of a telomeric repeat amplification protocol (TRAP) results in increased reliability, linearity and sensitivity. Nucleic Acid Res 1995;23:3794-5.

46 Holt SE, Norton JC, Wright WE, Shay JW. Comparison of the telomeric repeat amplification protocol (TRAP) to the new TRAP-eze ${ }^{\mathrm{M}}$ telomerase detection kit. Method Cell Sci 1996;18:237-48.

47 Miura N, Horkawa I, Suzuki $M$, Ohmura $H$, Ito $H$, Hirohashi $\mathrm{S}$, et al. Progressive telomere shortening and telomerase reactivation during hepatocellular carcinoma. Cancer Genet Cytogenet 1997 (in press).

48 Hiyama E, Kodama T, Shimbara K, Ito M, Hiyama K, Shay $\mathrm{JW}$, et al. Telomerase activity is detected in pancreatic cancer but not in benign pancreatic lesions. Cancer Res 1997 (in press).

49 Yoshida K, Sugino T, Tahara H, Woodman A, Bolodeoku J Nargund V, et al. Telomerase activity in bladder carcinoma and its implications for non-invasive diagnosis by detection of exfoliated cancer cells in urine. Cancer 1997 (in press).

50 Muller M, Heine B, Heivappell R, Emrich T, Hummel M, Stein $\mathrm{H}$, et al. Telomerase activity in bladder cancer, bladder washings and in urine. Int $\mathcal{f}$ Oncol 1996;19:1169-73.

51 Yoshikida K, Sugino T, Goodison S, Warren BF, Nolan D, Wadsworth S, et al. Detection of telomerase activity in exfoliated cancer cells in colonic luminal washings and it related clinical implications. Br $\mathcal{F}$ Cancer 1997 (in press)

52 Langford LA, Piatyszek MA, Xu R, Schold SC, Wright WE, Shay JW. Telomerase activity: A prognostic indicator in ordinary meningiomas. Hum Pathol 1997 (in press).

53 Murnane JP, Sabatier L, Marder BA, Morgan WF. Telomere dynamics in an immortal human cell line. $E M B O f$ 1994;13:4953-62.

54 Bryan TM, Englezou A, Gupta J, Bacchetti S, Reddel RR. Telomere elongation in immortal human cells without detectable telomerase activity. $E M B O \mathcal{F}^{1995 ; 14: 4240-8 .}$

55 Holt SE, Wright WE, Shay JW. Regulation of telomerase activity in immortal cell lines. Mol Cell Biol 1996;16:29329.

56 Feng J, Funk WD, Wang S-S, Weinrich SL, Avilion AA, Chiu C-P, et al. The RNA component of human telomerase. Science 1995;269:1236-41.

57 Norton JC, Piatyszek MA, Wright WE, Shay JW', Corey DR. Inhibition of human telomerase activity by peptide nucleic acid oligomers. Nature Biotech 1996;14:615-19. 